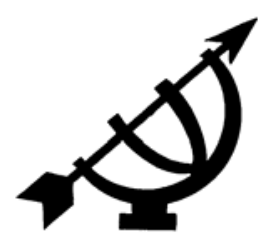

\title{
Presuppositions and the challenge to objectivity in late-modern philosophy of science: causes and possible remedies
}

\author{
R. Coletto \\ School of Philosophy \\ Potchefstroom Campus \\ North-West University \\ POTCHEFSTROOM \\ E-mail: Renato.Coletto@nwu.ac.za
}

\begin{abstract}
Presuppositions and the challenge to objectivity in latemodern philosophy of science: causes and possible remedies
\end{abstract}

The history of late-modern philosophy of science introduces us to a growing emphasis on presuppositions accompanied by a growing relativistic attitude concerning the possibility of scientific objectivity. Aspects of the latter historical developments are traced in some of the most important philosophers of science of the 20th century. An analysis of the possible causes of the phenomenon is also provided. The predominance of the freedom-pole of the humanist ground motive requires a conception of science in which the creative presuppositions of the knowing agent play an increasingly crucial role. Two "remedies" for a more balanced understanding of the role of presuppositions are indicated. The first one has to do with the recognition of a broad variety of ideological standpoints, stemming from different religious commitments. The second one recommends the recognition of the universal order for reality, which implies two consequences. First, our presuppositions do not have the power of determining our scientific observations of reality completely. Second, scientific research does not proceed only according to our presuppositional frameworks but follows a structural order. A few reflections on the nature of scientific objectivity conclude the article. 


\section{Opsomming}

\section{Vooronderstellings en die uitdaging daarvan aan objektiwiteit in die laat-moderne wetenskapsfilosofie: oorsake en moontlike oplossings}

Die geskiedenis van die laat-moderne wetenskapsfilosofie word gekenmerk deur die groeiende klem op vooronderstellings wat hand aan hand gaan met 'n groeiende relatiwistiese houding ten opsigte van die moontlikheid van wetenskaplike objektiwiteit. Aspekte van laasgenoemde historiese ontwikkeling word in sommige van die belangrikste wetenskapsfilosowe van die twintigste eeu nagespeur. 'n Analise van die moontlike oorsake van die verskynsel word ook gegee. Die sterk posisie van die vryheidspool van die humanistiese grondmotief vereis 'n wetenskapskonsepsie waarin die skeppende voorwaardes van die kennende agent 'n toenemend deurslaggewende rol speel. Twee "geneesmiddels" vir 'n meer gebalanseerde verstaan van die rol van vooronderstellings word aangedui. Die eerste een het te make met die erkenning van 'n breë verskeidenheid ideologiese standpunte wat voortspruit uit verskillende religieuse verbintenisse. Die tweede een stel voor dat 'n universele orde vir die werklikheid erken word, wat twee konsekwensies veronderstel. Eerstens, ons vooronderstellings het nie die vermoë om ons wetenskaplike waarnemings van die werklikheid volkome te determineer nie. Tweedens, wetenskaplike navorsing volg nie net ons vooronderstellingsraamwerke nie, maar volg 'n strukturele orde. Die artikel sluit af met 'n aantal opmerkings oor die aard van wetenskaplike objektiwiteit.

\section{Introduction}

The recognition of the role of presuppositions in science is perhaps the most significant feature of the philosophy of science of the 20th century. I will use the term presuppositions (without other qualifications) to indicate generically all kinds of non-scientific or pretheoretical assumptions, beliefs, worldviews which might be related to science. The received view insisted on the objectivity of science, which meant the exclusion of all non-scientific and metaphysical elements from scientific research itself (Botha, 1988:40 ff.). But the growing awareness of the role played by frameworks, paradigms and interpretation in general, in the long run imposed a much more modest view of the objectivity and rationality of science. In some cases scientific objectivity was challenged and even endangered. By tracing these developments in contemporary philosophy of science it will become apparent, I believe, that relativism and loss of confidence about objectivity gradually increased in the late-modern 
era. 1 The main question addressed here is: what are the causes of this phenomenon? After tackling this question, this article offers a few suggestions to improve our understanding of the nature and role of presuppositions and to counteract the relativism of contemporary philosophy of science.

My historical analysis will pass through the works of Popper, Polanyi, Kuhn and Feyerabend. ${ }^{2}$ By beginning my analysis from Popper I would like to explore briefly a philosophical system that is not fully implicated in the relativism of late-modern philosophy and for this reason constitutes a kind of background to more recent (and radical) developments.

\section{Popper: opening the door to presuppositions}

In a rather direct dialogue with Kuhn, Popper (1970:51) claims that the whole idea of paradigms influencing the scientific research was anticipated by himself already in 1934, in the preface to his book The logic of scientific discovery. Popper does not use the term paradigm, of course, but he goes as far as admitting that "we approach everything in the light of a preconceived theory" (Popper, 1970:52). Popper's idea of a "framework", however, is by no means as demanding as Kuhn's notion of paradigm: it does not impose itself on generations of scientists, demanding a committed loyalty. It does not resist the advent of a new paradigm. It does not prescribe problems, methods, theories and even instruments. It does not affect the scientist to the extent that the latter can only practice science from "within" a given paradigm.

$1 \quad$ I prefer to use the term "late-modern" (instead of "postmodern") because the former implies a closer connection between modernity and postmodernity. Postmodernity is not situated "after" modernity but in many ways is rather to be considered as part of it (cf. Coletto, 2007:16-17). For example, the analysis of several artistic disciplines brings Chabot (1991:35-38) to the conclusion that only in some of these disciplines modernity is opposed, while in others it is continued, re-affirmed and so on.

2 The choice of these thinkers is due to the fact that they deal specifically with philosophy of science, they are (among) the most influential philosophers of science of the period in question and their philosophies are good examples of the themes I intend to substantiate. By proposing these authors, however, I am not ignoring that in the same period others have resisted the growing scepticism towards objectivity. One can mention for example those who supported realist tendencies (e.g. Boyd, 1983; Mc Mullin, 1991) or rationalist tendencies (NewtonSmith, 1981). Even positivism is not totally absent from the picture. It will be admitted, however, that counter-instances like these are clearly less influential and authoritative than the mainstream schools in philosophy of science. 
Yes, we are "caught up" in paradigms, admits Popper, but we are free to leave them at any time. Yes, we then have to enter a new paradigm, grants Popper. But it will then always be "a better and roomier one" (Popper, 1970:56). Paradigms can always be critically discussed and compared (Popper, 1970:57). The dramatic picture offered by Kuhn is therefore dubbed by Popper (1970:56) as "the myth of the framework".

Apart from frameworks, for Popper there are also "extra scientific beliefs (such as a faith in the power of critical discussion) which a scientist need accept" (Popper, 1963:107). Such presuppositions grant the progress of science and allow the scientific practice itself. They are non-negotiable and should be held in common by all scientists. Unfortunately, Popper does not articulate this argument thoroughly.

Popper's discussion of philosophical issues is far more elaborated, although there is a certain degree of ambiguity in his attitude towards "metaphysics". On the one hand, as Stafleu (1987:253) observes, it is clear that Popper has his own ontological preferences. For example, he has convictions concerning the importance of the hypothetical-deductive method, about logic, realism, objective truth, the existence of natural laws (which are inborn but independent of humankind) and so on. Popper argues with vigour in favour of his metaphysical convictions. On the other hand Popper often seems to shy away from "metaphysical" issues, as if they might be potentially dangerous or "bewitching". On this point I agree with Botha (1986: 436-438) on the necessity of a second criterion of demarcation, to distinguish between "good and bad" metaphysics.

It might be concluded that Popper attributed a rather limited role to presuppositions. Yet his position represented an important breakthrough, compared to the positivist point of view. In Popper's philosophy the role of expectations and frameworks at least started to be mentioned in a positive way. They were no longer something that should be simply kept out of science.

The human subject was not seen anymore as a neutral observer collecting facts that speak by themselves. Popper argued that creativity and imagination are essential to propose scientific theories. Sometimes good scientific ideas can even initially be suggested by "stories" which are not really different from myths. The difference is that the "scientific myths" undergo open and informed criticism (Popper, 1963:127). Although Popper cannot be called a subjectivist, he recognised a more active role to the subject of knowledge. 
Polanyi continued Popper's journey and reached a more relativist position.

\section{Polanyi: recognising and classifying presuppositions}

In this section I'm going to focus mainly on the initial phases of Polanyi's philosophy, as illustrated in his work Science faith and society (Polanyi, 1946). ${ }^{3}$ At that stage, Polanyi (1946:42) distinguishes two classes of presuppositions: general and particular assumptions, though the distinction is not very systematic or even precise. In addition he sometimes speaks of "ideals" (Polanyi, 1946: 71) that look mainly like moral values.

Now, all the ideals, beliefs or presuppositions indicated above, are to a large extent shared by all scientists, irrespective of their faith and other commitments. At this stage of his career, this is an essential element in Polanyi's thought: presuppositions exist and play a role, they influence science and even make it possible. But most importantly, they are the common property of all scientists. They do not divide the scientific community. On the contrary, they unite it (Polanyi, 1946:55-56).

Polanyi also admits, however, that some presuppositions do create differences among scientists. The three types of premises mentioned above are pre-scientific in nature, but there are "ultimate presuppositions" (Polanyi, 1946:85) that belong to the scientific level. 4

3 Polanyi's recognition of a broader influence of presuppositions in Personal knowledge (Polanyi, 1958) is not very different in its basic structure, from what Kuhn proposes. However, as these insights are more articulated in Kuhn's work, I will rather describe these new developments in the next section, dedicated to Kuhn.

$4 \quad$ At the very beginning of my introduction I have stated that my focus will be on the role of pre-scientific presuppositions. The reason is that the influence of scientific presuppositions (e.g. theorems, axioms) on science has seldom been a matter of dispute among philosophers. Occasionally, however, in this article I also refer to the role of scientific presuppositions in Polanyi and Kuhn because it integrates their discourses on presuppositions. Of course different philosophers classify presuppositions differently and draw differently the line between scientific and pre-scientific presuppositions. For some, for example, philosophical presuppositions are scientific (Dooyeweerd), while for others (e.g. Popper) they are pre-scientific. Though the criterion for demarcation is too complex to be properly discussed in this article, I suggest that the nature of a presupposition is strongly determined by the context/attitude in which it is elaborated. For example, a belief that is accepted or shaped in the context of religious commitment belongs to the level of pre-scientific presuppositions or ground motives. On the other hand, presuppositions that are shaped in the 
In this context Polanyi (1946:88) mentions for example mechanism, rationalism and empiricism and observes that their proponents did not just regard them as complementary to each other. This raises a question: do they not constitute a threat to the unity and objectivity of the scientific community? Polanyi insists: although the "ultimate presuppositions" adopted by scientists are different, they are "fundamentally based on common ground" (Polanyi, 1946:85).

If we compare it with Popper's position, Polanyi's view represents an important step forward in many respects. In his work the premises of science are taken seriously and explored. It is understood that these premises have an influence on the scientific process. Certain (scientific) presuppositions are shared only by a particular community, or in a certain epoch (e.g. the premises behind classical physics). Yet most of the premises are shared by all scientists (nobody can practice science, for example, without believing in its value).

These are not Popper's presuppositions, which can be abandoned at any moment with the help of rational criticism. According to Polanyi (1946:90-92), for example, ultimate presuppositions direct even our criticism, our experiments, our tests. All this creates a distance between Polanyi and Popper and brings Polanyi closer to Kuhn's idea of paradigms. But presuppositions in general, in Polanyi's system, do not threaten science or communication because they are held in common, to a large extent, by all scientists. Polanyi links the presuppositions to the scientific tradition and community, thus granting science the possibility of dialogue and to retain a considerable authority and legitimacy.

In addition, Polanyi's presuppositions reach "deeper" levels than in Kuhn: they point towards the area of personal belief. Polanyi comes very close to the notion of religious ground motive, which was indicated as the root of scientific thought in the neo-calvinist tradition (see section 6). In fact, in his view scientific presuppositions are grounded into pre-scientific premises and these are linked to our deepest commitments. They refer to a "spiritual reality", to "spiritual resources", to an "act of devotion", and to "faith" (Polanyi, 1946:15, $54,55,76)$.

context of theoretical reflection are scientific in nature. Further suggestions concerning the differences and similarities between scientific and pre-scientific presuppositions are sketched by Coletto (2007:18-19). 
In Science faith and society Polanyi (1946) follows a rather "conservative" line, characterised by a defense of scientific unity, authority and tradition. In Personal knowledge (1958) he attempts acknowledging to a larger extent the conflicts created by different premises. But in order to learn more on this topic we can turn to Thomas Kuhn. In his work, the radical fractures created by paradigm changes are recognised and dealt with in a more articulated way.

\section{Kuhn: the paradigm as presuppositional framework}

In The structure of scientific revolutions (from now on The structure) a presuppositional framework is finally recognised as the cause of substantial differences in the practice of (both normal and revolutionary) science. My main argument in this respect is that Kuhn, by introducing the paradigm concept, has recognised a broader role and influence of presuppositions. Though the paradigm contains not only pre-scientific presuppositions, Kuhn's notion of paradigm always includes pre-scientific elements. It can therefore be granted that whenever Kuhn acknowledges any influence of paradigms or matrixes on science, it is to a considerable extent the influence of pre-scientific elements, which are inseparable from the scientific components of the paradigm.

Given the many and complex changes introduced by Kuhn in his view of paradigms, it would be very demanding to comment on his philosophy by following its historical development step by step. In addition, such an effort would not be particularly fruitful. I will rather try to individuate a few characteristics of Kuhn's idea of a paradigm (later matrix and exemplar) that are sufficiently stable through the changes. On this basis, I will try to compare Kuhn's position with the views of his predecessors, in particular Popper and Polanyi.

For example, paradigms (but also matrixes and exemplars) while accounting for the consensus of a certain scientific community 5 also make more room for the recognition of dissensus than in the past. On the one hand paradigms create differences only between different scientific epochs, not within the same epoch. In this sense, Kuhn's view is not totally different from Polanyi's: under the same paradigm, a discipline is granted the necessary homogeneity.

5 According to Hoyningen-Huene (1993:132 ff.) the initial reason why Kuhn introduced the idea of a paradigm is that it was supposed to account for the consensus existing within a scientific community. 
On the other hand, in The structure the successive paradigms contradict each other to a large extent. This is due to the fact that each new paradigm is supposed to solve problems which were not solvable under the previous paradigm (Kuhn, 1970a:92). The old paradigm is not simply modified, it is substituted by a new one which is supposed to provide the means to solve the crisis. For Kuhn, in fact, the new paradigm is at least antagonistic to the one which is substituted. This introduces the idea of (theoretical) antithesis, which is a new and important idea provided by Kuhn.

Secondly, paradigms (and their subsequent elaborations) change the world they constitute or help constituting. Since The structure Kuhn introduced the idea that paradigms are "constitutive of nature" (Kuhn, 1970a:110). They are part of that phenomenal world which is accessible to a specific community. Now, neither Popper nor Polanyi would ever have pushed the role of presuppositions thus far. For Polanyi the world is one and the truth is one, although the complexities of both require a great deal of openness and humbleness from the scientist. But for Kuhn paradigms become part of the phenomenal world that we explore scientifically. This is a world that we constitute and because we hold to different paradigms we constitute a plurality of phenomenal worlds. In this sense then, the weight of paradigms and their subsequent elaborations is much heavier than previous forms of presuppositions recognised by previous philosophers of science.

Thirdly, paradigms and all their subsequent elaborations determine science to an extremely large extent. As they are constitutive of the world, they constitute science even more. In The structure paradigms determine both the form and the content of scientific research, the problems, the questions, the methods, the instruments, the solutions! But even exemplars shape and determine the convictions and the results of the scientific community. They are not formal rules, they are rather learned by paradigmatic examples and "ostensions". But their effects are still very similar to those of paradigms: they determine scientific research to a large extent. Exemplars determine the similarity relations that are at the basis of our way of exploring the world (Kuhn, 1974:482).

All these considerations bring us to the conclusion that in Kuhn's philosophy the role of presuppositions in the shaping of scientific research was recognised more than in the past. At the same time, unfortunately, the objects of knowledge seem to play a more limited role. Kuhn tried to avoid complete relativism, but had to admit at least that his philosophy promotes "partial relativism" (Kuhn, 1970b: 
264-265). He was aware of the threat of complete anarchism and tried to protect the reliability of science from it. Feyerabend, on the other hand, saw anarchism as a wonderful opportunity, leading towards a better conception of science.

\section{Feyerabend: science as a presuppositional system}

Although Feyerabend provided some sort of demarcation criterion, in a context of high academic discussion, he did not believe in a real separation between scientific and non-scientific, between science and life (Feyerabend, 1975:19). He complains, for example, that a rigid demarcation is introduced between sciences: physics is distinguished from theology and from philosophy (Feyerabend, 1975: 19). Then science is distinguished from life and from belief. According to Feyerabend it is not understood that science is also a belief, a demanding practice perhaps, but still a belief that cannot be completely justified.

Feyerabend considers science as a belief system, while he can also speak of the "scientific content of some myths" (Feyerabend, 1975: 49 , footnote 7 ). The belief in science should be treated as any other belief. There are other options available: one could prefer to believe in voodoo or some ancient myth. Science should not be compulsory for our education and there should be a "separation of state and science" (Feyerabend, 1975:301), as the state has already separated itself from any specific church or religion (Feyerabend, 1978: 106).

In his work there remains a sense in which myth and scientific elaborations can be distinguished. Scientific elaborations can be seen as articulations of a basic myth. Some myths are elaborated into all types of theories. Others are never elaborated, although the possibility remains always available. In any case, science is not more rational than other activities. Its supposed objectivity and rationality are unmasked as pretensions the moment we analyse the concrete ways in which science has progressed through history. These ways do not exclude ad hoc adjustments, propaganda and so forth. Science is like any other human affair: it progresses irrationally, it needs to resist common sense and to proceed counterinductively.

Our exploration has thus moved from a time (the positivist era) when presuppositions were excluded from science, to a time when some philosophers suppose that science itself becomes a kind of belief. Or at least, it is not very clear what distinguishes science from its 
presuppositions. It might be argued that Feyerabend's anarchist philosophy is a rather peculiar point to conclude our exploration. Admittedly, our historical analysis could be extended to more recent times and to more moderate positions. Yet even in that case it would not yield significantly different results. Generally speaking, the knowing agent/community (and his/its presuppositions) is still the main focus of our philosophies of science, while the notion of objectivity is gradually weakened. It is therefore time to conclude this historical journey and to try and interpret the "symptoms" that have been observed.

\section{Attempting a diagnosis}

\subsection{From nature to freedom}

Dooyeweerd's theory of religious motives remains, I believe, one of the most suggestive ways of looking at the developments described up to now. Dooyeweerd could not write very much on the philosophers of science mentioned above (he died in 1977). Yet he provided a framework for the understanding of humanistic thought, including philosophy of science. In his view humanist thought, like all theoretical achievements, is regulated by a religious ground motive, a spiritual motive directing culture in a humanistic direction. 6

This humanist religious ground motive is constituted by two poles: the pole of nature and the pole of freedom, which are in dialectical tension (Dooyeweerd, 1984, 1:190-495). The pole of nature is dominated by the ideal of science, implying the scientific control of nature by man. The motive of nature, aiming at the control of nature, soon came into conflict with the pole of freedom. In fact, control over nature also means control over the human being, who is after all part of nature. Once rigid control is exercised over all nature, there is no more space for human freedom (Dooyeweerd, 1979:152-153). The conflict can be illustrated as follows. The motive of autonomous

6 From a reformational point of view the term religion/ous does not necessarily refer only to "classical" religions like Christianity or Islam. It includes also the convictions of humanists, atheists, positivists, marxists and all those who "interpret" life in some way or the other (i.e. all human beings). Roy Clouser observes that "a belief is religious provided that (1) it is a belief in something(s) or other as divine or (2) a belief concerning how humans come to stand in proper relation to the divine". As Clouser (1991:22-23) defines divine as "having the status of not depending on anything else", it is clear that all human beings have "religious" beliefs about some "ultimate" reality (e.g. matter, rationality, et cetera). 
and creative freedom of the human person is incompatible with the acceptance of an order of nature, constraining human freedom and revealing its heteronomous character. But the motive of nature, promoting the idea of the dominion of nature through science, requires a deterministic and mechanistic conception of the world, which leaves no room for the free and autonomous human subject. In Dooyeweerd's words therefore, "nature is revealed as the relentless enemy of freedom" (Dooyeweerd, 1959:52; translation - RC).

It is not possible to find a synthesis or a reconciliation between the two opposite poles of the same humanistic ground motive. ${ }^{7}$ The inevitable outcome, according to Dooyeweerd, is to attribute the primacy to one of the two and simultaneously depreciate the other. But the depreciated pole, usually, in due time finds a way to regain the primacy and to overcome the opposing pole. The reason is that the world is an integral and coherent reality, which resists the absolutisation of one aspect to the detriment of the others. Declaring one dimension of reality as primary, inevitably leads to a tension in which the other dimensions call for recognition. In sociology for example, initially humanism was directed (by the pole of nature) towards the absolutisation of the method of the natural sciences. When it became clear that this was gradually eliminating human freedom from the scene, the ideal of freedom regained strength and imposed the absolutisation of the "historical method" (Dooyeweerd, 1979:207).

Historicism 8 viewed all of reality from the perspective of historical development. Just like human culture, also the planets, plants and animals were products of development. This seemed to suit better and to strengthen the ideal of the free personality, which is closely linked to the freedom-pole of the humanistic ground motive, and dialectically opposed to the ideal of science of the nature motive. The ideal of the free personality, previously "defeated" by the ideal of science, gradually started to claim its rights. The mechanistic world picture of the previous phase was abandoned in favour of an organismic worldview. The natural scientist used to divide a complex

7 A religious dialectics, according to Dooyeweerd (1984, 1:64-65), cannot be solved by way of theoretical synthesis.

8 Basically, we can say that Dooyeweerd uses the term historicism to indicate relativism, i.e. as the result of anchoring philosophy to the pole of the autonomous personality (i.e. to the human subject). Admittedly, this is a rather unique use of the term. 
phenomenon into its simplest elements. The new method took its departure from the individual whole, and tried to understand the function of the parts in terms of the whole. In the next section we will observe more in detail the effects of the ideal of freedom on philosophy of science and more in particular on the role of frameworks and presuppositions.

\subsection{Presuppositions and the ideal of freedom}

At this point we can focus on the basic conflict within the humanistic ground motive. On the one side we have the control of nature through science. On the other we have the freedom of the personality. The first ideal stresses science, the second one freedom. The first stresses nature, the second man and his creativity. It is enough to keep in mind these basic facts, in order to approach the problems discussed so far from a new perspective. We have observed a rather limited segment, historically speaking, of the development of humanistic philosophy of science. Yet it appears likely to suppose that positivism was inspired by the theme of the control of nature via natural science. Great importance was attributed to nature itself. The intervention of the human personality was experienced as an intrusion. The role of the scientist was reduced to a minimum and characterised by objectivity and neutrality. Facts were supposed to speak for themselves, while the subjectivity of the scientist (which includes his religious and metaphysical presuppositions) was ruled out of bounds.

Popper's philosophy inaugurated a transitional phase. He tried to create a synthesis between the two poles of the humanistic motive (cf. Stafleu, 1987:255-256). He was trying to save both scientific control and human creativity, but was still rather ambiguous about the role of presuppositions (see section 3). With Kuhn, the emphasis falls more directly on human creativity. The importance of history emerges with new force. The observer creates a new world by his own way of seeing. Paradigms, the ultimate foundations of science, become the central notion of a new understanding of science. With Feyerabend we see the triumph of the free personality, unrestrained by any heteronomy.

We are now able to provide a possible answer to the general question concerning the causes of the objectivity crisis in late-modern philosophy of science. The depreciation of the ideal of science and the hegemony of the ideal of freedom of the autonomous personality demand a new conception of science where objectivity and rationality are gradually downplayed. They demand a science in which 
presuppositions play a larger role, a science which does not impose its conclusions. But with the radical reduction of objectivity, authority and universal validity, the legitimacy of science is also gradually endangered.

On the basis of this "diagnosis", I will propose two suggestions. The first one (section 7.1) is meant to improve an understanding of the role and nature of presuppositions, the second one (section 7.2) aims at balancing the excessive emphasis on presuppositions.

\section{Sketching two suggestions}

\subsection{Recognising the religious commitments and the consequent ideological plurality}

My first suggestion is not about relativising the role of presuppositions in science. On the contrary, it is about recognising that presuppositions are always related to the religious root of theoretical thinking. A corollary of this suggestion is that we also need to recognise without hesitations the broad confessional or ideological plurality of presuppositions (e.g. christian, humanist, positivist, pragmatist and so on). ${ }^{9}$

In some recent philosophies of science the point of contact between theoretical thought and the religious or worldviewish root in the human person has not been acknowledged. We are left with hypotheses or "expectations" which can be abandoned at any time (Popper), or with paradigms in which the role of the deepest presuppositions is insufficiently explored (Kuhn).

Some authors were closer to the discovery of the religious root of thinking. Polanyi speaks of beliefs behind our theories, of faith and "spiritual resources". Unfortunately this important insight is not always accompanied by a recognition of a plurality of confessional standpoints. Polanyi's emphasis (especially in the first phases of his

The space at my disposal is not sufficient to discuss the necessity of recognising a broader typological variety of presuppositions as well (i.e. there are many types of presuppositions). On this topic reformational philosophers have provided numerous contributions. I will only mention for example Wolters' (1989:21 ff.) discussion of the different roles played by worldviews and religious ground motives. See also Klapwijk (1987 and 1989), Olthuis (1989), Wolterstorff (1989), Botha (1993 and 2002, especially p. 210-216). A short but very interesting contribution on this topic has been provided by Duvenage (1985). 
career) is rather on the unity of the scientific community and the common ground created by the same ideals.

In general, the humanist tradition has been ready to explore the influences that a large variety of factors have on science. Psychological factors, social, economic, cultural factors have been shown to have a meaningful influence. But the eventual influence of the religious dimension has been kept out of the picture. Botha (1994:27) has expressed the hope that a certain trend within contemporary philosophy of science (the cognitive-historical school of among others N.J. Nersessian) might "provide interesting new perspectives (...) in which the role of religious factors is not excluded". But for the moment this seems to remain just a hope.

Dooyeweerd's (1984, 1:3-67) transcendental critique of theoretical thinking was a decisive step in the recognition of the link between science and religion, as well as the confessional plurality of presuppositions. His critique allows to maintain that a plurality of religious motives are the basic pretheoretical starting points of philosophy and culture in general. They influence theoretical thinking by providing a triplex fundamental idea, which Dooyeweerd $(1984,1: 68)$ calls a transcendental or ground idea. The first "side" of this idea provides an answer to the question concerning the origin of meaning. The second side deals with the unity of meaning and the third one deals with the relation of coherence and diversity between the different aspects of created reality (Dooyeweerd 1984, 1:93-102).

The three questions are interrelated. According to Dooyeweerd (1984, 1:69), the acceptance of a unique origin of all meaning (or of two original principles opposed to each other) determines whether one accepts or not (see second question) the integral unity of meaning at the root of the modal aspects. And the answer given to this second question determines how one understands the mutual relation and coherence of meaning of the modal aspects (third question). All this influences philosophical thinking. However, the special sciences rely on philosophy for their theoretical conception of reality and for their method of forming concepts and problems. The specific meaning of analogical concepts is different between different sciences because their modal points of view differ and their basic ground idea differs. It is therefore clear that the triune transcendental idea, on the basis of a religious ground motive, influences both philosophy and the special sciences.

A plurality of confessional commitments creates a plurality of presuppositional frameworks which need to be recognised as well. 
Though admitting that one "paradigm" may obtain the majority of consensus in a certain period, Dooyeweerd recognised more clearly than Kuhn that it is possible that different schools coexist and interact in the same period, without necessarily adopting the same "paradigm". In this sense Dooyeweerd would have agreed with Feyerabend, who noticed this phenomenon for example during the nineteenth century, in physics (Feyerabend, 1970:207-208). Unlike Feyerabend (e.g. 1975:30), however, Dooyeweerd did never maintain that the proliferation of frameworks and theories should constitute an appropriate aim of science.

A better understanding of confessional plurality would help obtaining a better assessment of the nature and role of presuppositions. It would not be sufficient in itself, however, to heal the widespread philosophical skepticism concerning scientific objectivity. On the contrary, it might even deepen the relativist mood of contemporary philosophy of science. To avoid this undesired result, the recognition of the plurality of confessional standpoints must be accompanied by the recognition of creational structures. My second suggestion, therefore, deals with the recognition of a universal and structural order for reality.

\subsection{Recovering the real world}

Reformational philosophers have never abandoned the idea that, apart from our frameworks, there must be some type of real world out there, a reality which is not influenced by our views. And as we human beings are part of this created reality, the latter must be accessible to our enquiries, to a considerable extent. Here we meet the fundamental theme of a creational order, so characteristic of the reformational approach. As I have dealt more extensively with this topic in another article $\mathbf{1 0}^{\mathbf{1 0}}$ w will limit myself to a few notes here. I would define this structural order as a stable and universal order, accessible to the knower and conditioning scientific thought.

The created order is not simply constructed by the subject. It cannot be "boxed" into just any view or theory. It is not just what we want it to be. But at the same time it is accessible to scientific investigation. One of the consequences of this basic insight is that our theories do not have the power of shaping or determining our scientific observations of reality completely. Reality is to a certain extent indepen-

10 See R. Coletto: The "eclipse" of the object of research in late-modern philosophy of science. (Forthcoming: Tydskrif vir Christelike wetenskap, 44(1-2) 2008.) 
dent from our theories and frameworks. Stafleu (1987:125) offers a good summary of this important theme when he says:

Some logical-empiricists thought (...) that the observational results, the 'sense data', are completely independent of any theory. But this view seems to be untenable. Some modern philosophers tend to adhere to the other extreme by assuming that any observational result is completely determined by a theory. An intermediate position seems to be more in accord with scientific practice. We argued that observational results can only be acquired in a theoretical context, but nevertheless have a certain autonomy (...) They can be transferred from one theory to another one. If this were not the case theories could not be tested and competing theories could not be compared.

Accepting the existence of a universal structural order has another important consequence: science does not develop primarily in accordance with our own frameworks, but in accordance with the clues provided by the created order. In this context Stafleu (1987:151-157) suggests an explanatory model accounting for the empirically discovered natural order (cf. Stafleu, 1987:157).

In this model, three fundamental "axes" of scientific research are identified. They are linked to ontological distinctions such as the theory of modal aspects, the distinction universal-typical and the distinction between the law side and the subject side of reality. These axes of research allow the fourfold scientific search for objectivity, application, universality and structure. This shows that scientific research does not proceed in a chaotic manner, but rather follows a natural order. In the past few decades, several philosophers have argued that science develops under the guidance of a paradigm (Kuhn), a research programme (Lakatos, 1970:91-196) or a research tradition (Laudan, 1977:70-120). They have shown the intimate relation between a worldview (or framework) and scientific work. But, as Stafleu observes: "none of them has recognized the natural order of these various directions of scientific research" (Stafleu, 1987:157).

Unfortunately, the late-modern philosophy of science has very often been nominalist and subjectivist, and therefore has been inclined to deny any order external to the subject. This has caused several anomalies. In particular, the denial of an order external to the subject has gradually contributed to placing the locus ordinis within the subject himself. In this way the presuppositions of the knowing subject, his theories and views, have increasingly acquired an 
extraordinary importance to the detriment of another fundamental epistemic factor: the universal order for creation.

The reformational tradition recognises to a larger extent the reality of both presuppositions and conditioning structures. It does so, not by searching a fine balance between the two but by placing them into a new context. This context is the Biblical view of the world, in which the human subject is a religious being and the world is a creation including man himself. In this perspective, the different subjects and objects are not autonomous but are subjected to a "Law" or laws. The law does not constitute an inhibition of the freedom of the subject but rather constitutes the possibility itself of this freedom.

\section{Conclusion}

The recognition of a created order provides the needed external anchorage for scientific knowledge. The admission that presuppositions are not all that exists in science and we are constrained by a created order partially independent of knowing agents, counteracts relativism and provides a more balanced picture of the scientific enterprise. When this order is acknowledged, the recognition of the ultimate religious root of presuppositions is not necessarily to be considered a threat to scientific objectivity. But it is inappropriate to emphasise the role of presuppositions to the detriment of the structural order that the different sciences are supposed to investigate.

Late-modern philosophy did something positive when rejecting the notion of objectivity promoted under the "received view" of science. Objectivity should not be understood as correspondence to the facts. Theories are underdetermined by facts and facts are selected in a way that makes them at least partially theory-laden. But then objectivity cannot be interpreted as correspondence to the knowing subject either. The notion of objectivity that should be defended is correspondence to the law, or law-conformity. According to Stafleu (1987:241) it was precisely this type of respectful "submission" to the law that guided (for example) Kepler to the acknowledgment of laws that contradicted all hypotheses conceived up to 1600.11 And it is this type of search for objectivity that can allow us to avoid the relativistic tendencies of postmodern philosophy of science.

11 For an assessment of the relevance of the "Reformed view of the law" for modern science, see Stafleu (1987:239 ff.). 


\section{List of references}

BOTHA, M.E. 1986. "Bewitching" or confusing metaphysics: the demarcation between science and metaphysics according to Karl Popper. Koers, 51(4):430-440.

BOTHA, M.E. 1988. Objectivity under attack: rethinking paradigms in social theory - a survey. (In Marshall, P.A. \& Vander Vennen, R., eds. Social sciences in Christian perspective. Lanham: University Press of America. p. 33-62.)

BOTHA, M.E. 1993. The mediating role of metaphor and analogy in the relationship between science and religion. Tydskrif vir Christelike wetenskap, 29(4):60-73.

BOTHA, M.E. 1994. Understanding our age: philosophy at the turning point of the "turns"? The endless search for the elusive universal. Tydskrif vir Christelike wetenskap, 30(2):16-31.

BOTHA, M.E. 2002. Of light and limits: philosophy matters. Koers, 36(2):207225.

BOYD, R. 1983. The current status of scientific realism. Erkenntnis, 19(1):4590.

CHABOT, C.B. 1991. The problem of the postmodern. (In Hoesterey, I., ed. Zeitgeist in Babel: the postmodernist controversy. Bloomington: Indiana University Press. p. 22-38.)

CLOUSER, R.A. 1991. The myth of religious neutrality: an essay on the hidden role of religious belief in theories. Notre Dame: University of Notre Dame Press.

COLETTO, R. 2007. The legitimacy crisis in late-modern philosophy of science: towards a reformational response. Potchefstroom: PU for CHE. (Ph.D.thesis.)

DOOYEWEERD, H. 1959. Cinq conferences. La revue reformee, 10(3):3-76.

DOOYEWEERD, H. 1979. Roots of Western culture: pagan, secular and Christian options. Toronto: Wedge.

DOOYEWEERD, H. 1984. A new critique of theoretical thought. 4 volumes. Jordan Station: Paideia.

DUVENAGE, B. 1985. Christian scholarship as Word-bound scholarship. Potchefstroom: PU for CHE. (Potchefstroom Studies in Christian Scholarship.)

FEYERABEND, P.K. 1970. Consolation for the specialist. (In Lakatos I. \& Musgrave A., eds. Criticism and the growth of knowledge. Cambridge: Cambridge University Press. p. 197-230.)

FEYERABEND, P.K. 1975. Against method: outline of an anarchistic theory of knowledge. London: NLB.

FEYERABEND, P.K. 1978. Science in a free society. London: NLB.

HOYNINGEN-HUENE, P. 1993. Reconstructing scientific revolutions: Thomas S. Kuhn's philosophy of science. Chicago: The University of Chicago Press.

KLAPWIJK, J. 1987. Reformational philosophy on the boundary between the past and the future. Philosophia reformata, 52(2):101-134.

KLAPWIJK, J. 1989. On worldview and philosophy: a response to Wolters and Olthuis. (In Marshall, P.A., Griffioen, S. \& Mouw, R.J., eds. Stained glass: worldviews and social science. Lanham: University Press of America. p. 41-55.) 
KUHN, T.S. 1970a. The structure of scientific revolutions. Chicago: The University of Chicago Press.

KUHN, T.S. 1970b. Reflections on my critics. (In Lakatos, I. \& Musgrave, A., eds. Criticism and the growth of knowledge. Cambridge: Cambridge University Press. p. 231-277.)

KUHN, T.S. 1974. Second thoughts on paradigms. (In Suppe, F., ed. The structure of scientific theories. Urbana: University of Illinois Press. p. 459482.)

LAKATOS, I. 1970. Falsification and the methodology of scientific research programmes. (In Lakatos, I. \& Musgrave, A., eds. Criticism and the growth of knowledge. Cambridge: Cambridge University Press. p. 91-196.)

LAUDAN, L. 1977. Progress and its problems. London: Routledge \& Kegan Paul.

MC MULLIN, E. 1991. Comment on selective anti-realism. Philosophical studies, 61(1-2):97-108.

NEWTON-SMITH, W.H. 1981. The rationality of science. London: Routledge \& Kegan Paul

OLTHUIS, J. H. 1989. On worldviews. (In Marshall, P.A., Griffioen, S. \& Mouw, R.J., eds. Stained glass: worldviews and social science. Lanham: University Press of America. p. 41-55.)

POLANYI, M. 1946. Science faith and society. Chicago: University of Chicago Press.

POLANYI, M. 1958. Personal knowledge: towards a post-critical philosophy. London: Rutledge \& Kegan Paul.

POPPER, K.R. 1963. Conjectures and refutations: the growth of scientific knowledge. London: Routledge \& Kegan Paul.

POPPER, K.R. 1970. Normal science and its dangers. (In Lakatos, I. \& Musgrave, A., eds. Criticism and the growth of knowledge. Cambridge: Cambridge University Press. p. 51-58.)

STAFLEU, M.D. 1987. Theories at work: on the structure and functioning of theories in science, in particular during the copernican revolution. Lanham: University Press of America.

WOLTERS, A.M. 1989. On the idea of worldview and its relation to philosophy. (In Marshall, P.A., Griffioen, S. \& Mouw, R.J., eds. Stained glass: worldviews and social science. Lanham: University Press of America. p. 14-25.)

WOLTERSTORFF, N.P. 1989. On Christian learning. (In Marshall, P.A., Griffioen, S. \& Mouw, R.J., eds. Stained glass: worldviews and social science. Lanham: University Press of America. p. 56-80.)

\section{Key concepts:}

humanist philosophy: ground motive

philosophy of science

presuppositions

relativism

scientific objectivity 


\section{Kernbegrippe:}

humanistiese filosofie: grondmotief relatiwisme vooronderstellings wetenskaplike objektiwiteit wetenskapsfilosofie 